International Journal of Environment, Agriculture and Biotechnology
Vol-6, Issue-3; May-Jun, 2021
Journal Home Page Available: https://ijeab.com/
Journal DOI: $10.22161 /$ ijeab

Article

Peer-Reviewed Journal

\title{
Assessing Awareness about Volta Basin Authority, Code of Conduct and Water Governance Challenges in the Volta Basin
}

\author{
Abdul-Razak Zakaria ${ }^{1}$, Kenichi Matsui ${ }^{2}$
}

${ }^{1}$ Graduate School of Life and Environmental Sciences, the University of Tsukuba, Japan.
${ }^{2}$ Faculty of Life and Environmental Sciences, the University of Tsukuba, Japan.

Received: 20 Feb 2021; Received in revised form: 21 Apr 2021; Accepted: 11 May 2021; Available online: 28 May 2021

C2021 The Author(s). Published by Infogain Publication. This is an open access article under the CC BY license

(https://creativecommons.org/licenses/by/4.0/).

\begin{abstract}
River basin organizations have taken shape in different parts of Africa partly under the influence of international aid institutions that aimed to help prevent water conflicts among basin countries. The code of conduct and the Volta Basin Authority (VBA) exemplify one of most recent efforts to collaboratively govern a major transboundary basin of western Africa. The question, however, remains as to the extent to which culturally diverse local communities can be mobilized and integrated in water governance. No study has clarified this point. This paper, therefore, attempts to better understand local stakeholders' perceptions and needs to collaboratively govern transboundary water between Ghana and Burkina Faso. For this research, we conducted preliminary field visits and questionnaire surveys in both countries. We found that $84 \%$ of the respondents in Burkina Faso and $91 \%$ in Ghana did not know about the VBA. Some respondents, especially educated ones in both countries, did hear about the code of conduct. Regarding local needs for water governance, most respondents in Ghana expressed concerns about frequent flooding due to Bagre Dam spillage in upstream Burkina Faso that devastated their farms. This research then discusses how transboundary water governance in the Volta River Basin can be improved in the future.
\end{abstract}

Keywords - Volta River Basin, riparian awareness, water governance challenges, Burkina Faso, Ghana.

\section{INTRODUCTION}

Proponents of transboundary water management have long sought for an effective cooperation mechanism among basin countries partly to prevent or mitigate water conflicts (Islam and Susskind, 2013). As early as 1908, the United States and Canada established the International Joint Commission (IJC) by signing a treaty to collaboratively govern shared water resources (Chacko, 1932). Since then, many transboundary water agreements were signed partly to establish river basin organizations (RBOs), which, to some extent, affected how nations and jurisdictions may share water sources (Priscoli and Wolf, 2009). These organizations also have institutionalized water conflict resolution mechanisms (Schmeier, 2013).
Wolf et al. (2003) identified 17 water conflict prone river basins in the world, of which eight basins belonged to the African continent. Somewhat following American and European examples, African nations have formulated several transboundary water organizations, such as the Lake Chad Basin Commission (1964), Niger Basin Authority (1980), Permanent Okavango River Basin Water Commission (1994), and Zambezi Watercourse Commission (2004), among others. UN organizations were often involved in the formulation of these organizations. For example, in 1997 the UN Watercourses Convention emphasized international cooperation in managing transboundary watercourses. In western Africa, the World Bank, the Economic Community of West African States, and the European Union Water Initiative have supported the establishment of a cooperation mechanism among six 
riparian countries of the Volta River Basin since the 1990s (Opoku-Ankomah et al., 2006; World Bank, 2015; Yankey, 2019).

Partly in response to this transboundary collaboration movement, Burkina Faso and Ghana established the code of conduct for the sustainable and equitable management of the Volta Basin. This was facilitated under the Project for Improvement of Water Governance in the Volta Basin (PAGEV). To faithfully follow this code, the two countries established the Joint Technical Committee on Integrated Water Resource Management (JTC-IWRM) in 2005. At a follow-up validation meeting in 2006, the JTC-IWRM finalized the language in the code (Welling et al., 2014). The directorate of water resources in both countries jointly spearheaded the development of the code of conduct.

This code of conduct defined tasks and obligations of riparian states. It contains eight sections and 59 articles. Some articles provide guidelines for decision making and the implementation of water governance interventions. It laid out nine principles for the rational and sustainable use of basin resources which are somewhat similar to international water law principles on shared water resources (Ampomah et al., 2008). These principles are: (1) equitable resource use and participation, (2) cooperation, (3) regular data and information exchange, (4) notification of planned activity, (5) ecosystem protection and preservation, (6) non-maleficence, (7) emergency notification, (8) freedom for navigation, and (9) precaution and prevention (Yankey, 2019). The code of conduct, however, is not published for the readership of the public.

Despite this agreement, water resource use in both countries remains virtually unchanged partly due to lack of institutional frameworks to ensure the implementation of the code. The Volta Basin Authority (VBA) was expected to fill this gap. In 2004 a joint declaration agreement was signed by Burkina Faso and Ghana. A few months after the enforcement, these nations invited all the other riparian countries of the Volta Basin to join and formulate a similar transboundary water governance framework (Mali, Togo, Côte d'Ivoire, and Benin). In November 2004, all responsible ministers of the six basin countries came together and signed an agreement that established the Volta Basin Technical Committee (VBTC). On December 6 , 2005, these countries also signed a memorandum of understanding (MOU) to establish the Volta Basin Authority (VBA) (Opoku-Ankomah et al., 2006; World Bank, 2015; Yankey, 2019). These efforts resulted into the establishment of the Volta Basin Authority (VBA) in 2007 (which came into effect in 2009) (Global Water Partnership, 2014; Amuquandoh, 2016).
The establishment of this Authority was a major step toward a collaborative governance. The Volta River Basin affects water supplies for about 24 million people (as of 2010) and this number is expected to reach 33.9 million in 2025. Riparian communities in this Basin are largely rural and poor, engaging in small-scale agriculture (UNEP/GEF-Volta Project, 2013; Global Water Partnership, 2014). Considering this soci-economic situation along with cultural diversity, the fundamental question is how the VBA can implement its policies effectively among its diverse members, and to what extent local participation can be achieved. Article 6 of the Volta Convention mandates it to promote consultation and partnership among these people. It also encourages the implementation of integrated water resources management (IWRM) and the equitable distribution of benefits. As water conflicts tended to emerge due to dam construction and its release of reservoir water, which can flood lower basin communities, the VBA further instructed member nations to obtain its assessment and approval in order to execute infrastructure developments that have the potential to inhibit water flow (Yankey, 2019; IEADB, 2020). The 2015-2019 Strategic Action Plan of the VBA further aimed at enhancing stakeholder participation through enhanced communication (World Bank, 2015).

Gerlak and Schmeier (2018) noted that RBOs are effective when they contribute to behavioral change of riparian communities towards sustainable transboundary water resource governance. The effectiveness of the VBA, however, has been questioned by scholars. Gao and Margolies (2009) found that the Basin had suffered increasingly from deteriorating water quality in the last ten years. Several other scholars stressed poor coordination among the six countries for flood risk assessment and planning (Obrecht and Mead, 2014; World Bank, 2015; Yankey, 2019). The World Bank (2015) also observed increasing extreme climate events, continuing deforestation, and soil degradation. Yankey (2019) further noted that the VBA was not respected by stakeholders. IUCN (2012) encouraged the VBA to show tangible results and improvements to water users in order to have good community participation at transboundary levels.

One of the most contentious issues that gained attention from scholars was the controversy over Bagre Dam spillage near the Ghana-Burkina Faso border (Amuquandoh, 2016; Yankey, 2019). Some studied the effect of Bagre Dam spillage on downstream watershed areas in Ghana (Matthews, 2012; Mul et al., 2015; Ampomah, 2017). Another group of researchers focused on water allocation between the two countries (Andreini, 2002; Leemhuis et al., 2009; Baah-kumi and Ward, 2020). Some studies looked at institutional arrangement for 
undertaking integrated water resource management in this border area (Opoku-Ankomah et al., 2006; Agyenim, 2011).

However, for the VBA to engage in meaningful consultation and induce active participation among smallholders, it is imperative to better understand the level of awareness and needs among riparian communities (Koop et al., 2017). Awareness means a good comprehension of causative factors as well as effects and dangers associated with governance challenges. A lack of awareness of government policies on flood management by local communities in Ghana was identified as a major barrier to stakeholder participation in water resource protection (Gyireh and Nunbogu, 2015). They recommended the adherence of the principle of free, prior, and informed consent (FPIC) in engaging with the public regarding water governance. The international water law principles on shared water resources also emphasized the need for prior consultations with all stakeholders and the duty to cooperate and to negotiate, among others (Ampomah et al., 2008).

Heeding to these suggestions and partly attempting to fill out research gaps we identified above, this paper seeks to find factors that have prevented the effective implementation of transboundary governance in the Ghana-Burkina Faso border area. As the eight principles of the code of conduct generally emphasize the importance of meaningful participation and consultation among stakeholders, this paper tries to better understand riparian communities' awareness of critical water governance issues in the study areas. This examination can help identify factors that have prevented policymakers from effectively coordinating water policies in these two countries.

\section{METHODS}

\subsection{Study area}

As one of the most critical issues of the Volta River water use has been related to Bagre Dam spillage, we chose to focus on two main areas that have been reported to be most affected by the spillage, including Bagre District of the Eastern Central Region of Burkina Faso and the socalled Bawku zone of the Upper East Region in Ghana (Figure 1).

In 2019, we conducted a preliminary field visit in this area and interacted with some community members in order to collect information about dam spillage and flood impact issues. We found that downstream communities below Bagre Dam both in Burkina Faso and Ghana had frequently suffered from flooding due to its regular spillage (Gao and Margolies, 2009; IIED, 2020).

The town of Bagre is known for its agribusiness projects in connection to the dam. It is home to 19,164 people from various ethnic groups (City Population, 2020). The climate in this area is characterized by dry (harmattan) and wet (rainy) seasons with an average annual rainfall of $1,000 \mathrm{~mm}$ (Coche, 1998). Its vegetation is predominantly covered with scattered shrubs, short grasses, and acacia trees. Crop farming, livestock breeding, and fishing constitute main livelihood activities. Rice, maize, vegetable, and fruit plantations are main farming activities (City Population, 2020).

The economy of the Bawku zone largely depends on agriculture, which employs about $80 \%$ of the population (Ghana Statistical Service-Bawku Municipality, 2014). The climate here is characterized by the wet season from May to October and the dry season from November to April. An average annual rainfall ranges from $950 \mathrm{~mm}$ to $1,100 \mathrm{~mm}$. The vegetation here is like the study area in Burkina Faso. Riparian communities conduct limited irrigation by drawing water from the Volta River. Major food crops here include maize, rice, sorghum, pepper, watermelon, and onion (Ghana Statistical Service-Garu, 2014; MOFA, 2015). The construction of Kpalugu multipurpose dam in downstream Ghana commenced in April 2020. Once completed, it will be the first storage dam in this part of the Basin to provide irrigation water to farmers (Construction Review Online, 2020).

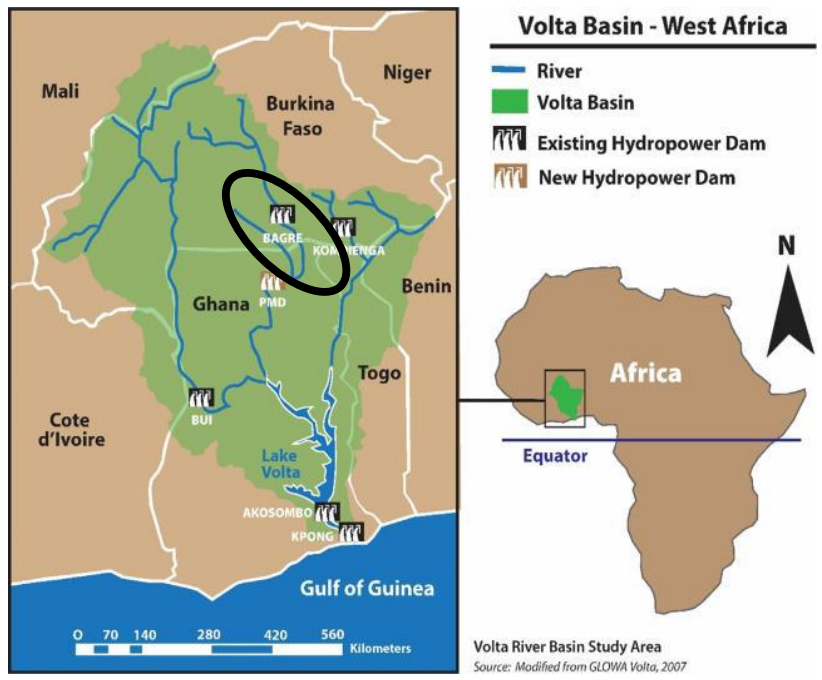

Fig. 1. Map of the Volta River Basin showing the study area in circle

(Source: Baah-kumi and Ward, 2020). 


\subsection{Data collection and analysis}

In December 2019 and January 2020, we conducted questionnaire surveys in the two study areas along the Volta River. In Burkina Faso's Bagre District, we randomly sampled 30 residents each at Poanga, Benkaku and Dirlakou communities. In the Bawku zone of Ghana, we randomly distributed the questionnaire to 50 residents each at Azum-Sapeliga, Gentiiga and Songo communities. Our selection of sampling sizes was based on the population differences between these two areas. A population of Bagre District was 19,164 (CityPopulation, 2020 ) and that of Bawku zone was 290,117 (Ghana Statistical Service, 2014). Due to their limited reading and writing skills, we obtained support from local enumerators and administered the questionnaire by translating English into local languages called Mossi in Burkina Faso and Kusaal in Ghana. The response rate was $100 \%$ in Burkina Faso and 99\% in Ghana. Altogether we collected 238 valid responses.

The questionnaire had three parts. The first part attempted to identify the socio-demographic characteristics of our respondents. The second part tried to understand community members' awareness about water governance in the Volta River Basin. The third part focused on water governance challenges. The questionnaire responses were coded and entered in the Statistical Package for Social Sciences (SPSS version 23) worksheet for analysis. Descriptive statistics in the form of frequencies and percentages were largely used to discuss the results. We also used the Pearson Chi-Squared to understand correlations between respondents' socio-demographic characteristics and their awareness (Kent State University Libraries, 2020).

The null hypothesis (Ho) of the Pearson Chi-Squared $(\chi 2)$ analysis was that there is no significant difference between respondents' socio-demographic characteristics and their awareness about the code of conduct, VBA, and being key stakeholders of VBA. The alternate hypothesis (Ha) was that there is significant difference between respondents' socio-demographic characteristics and their awareness about the code of conduct, VBA, and being key stakeholders of VBA. The null hypothesis was tested at 0.05 level of significance. Ho was rejected if the p-value is lower than the significance level. However, when the pvalue is higher than the significance level, then we accept Ho.

\section{RESULTS AND DISCUSSION}

3.1 Socio-demographic characteristics of the respondents
Among the 238 valid responses, 148 were from Ghana and 90 were from Burkina Faso (Table 1). In terms of gender $66 \%$ in Ghana and 50\% in Burkina Faso were males. The mean age among the Ghanaian respondents was 39.7 years old whereas that in Burkina Faso was 40.5 years old. About $93 \%$ of the Ghanaian respondents belonged to either the 40-59 age group (57\%) or the 18-39 age group (36\%). In Burkina Faso, the 40-59 age group consisted of 37\% whereas the 18-39 age group had 53\%. To place these age differences in a context, according to the World Bank (2020), average life expectancy in Burkina Faso is 61 years old, and that of Ghana is 64 years old (World Bank Group, 2020). Among them, 62\% in Ghana and 30\% in Burkina Faso were household heads.

The results on economic aspects show that the Bawku respondents (Ghana) were largely farmers (98\%). In Burkina Faso, $70 \%$ was farmers. The rest was mainly engaged in trading (18\%) and teaching (7\%). Only $1 \%$ of the Ghanaian respondents were engaged in trading on the contrary. These differences mean that, in Bagre District, the Bagre Dam irrigation project had induced occupation diversity. The residents here typically engage in fishing, rice farming and vegetable cultivation throughout the year. This town has attracted a small number of traders and artisans.

Regarding the duration of their residency in the study areas, we found that about $75 \%$ of the Ghanaian respondents lived for 5-20 years in the same community, whereas $65 \%$ of the respondents in Burkina Faso did so. About 5\% of the Ghanaian respondents lived in the same community for more than 40 years whereas none did so in Burkina Faso.

The education level of the respondents was low in both countries as 57\% in Ghana and 60\% in Burkina Faso had no formal education. In Burkina Faso, a small portion of the respondents had completed primary education (20\%) and junior high school education (10\%). In Ghana, the percentages of primary education $(16 \%)$ and junior high school one (12\%) did not show much difference from Burkina Faso counterparts. Also, $5 \%$ of the respondents in Burkina Faso had tertiary education whereas $4 \%$ in Ghana did.

Table 1. Socio-demographic characteristics of the respondents

\begin{tabular}{l|c|cc}
\hline $\begin{array}{l}\text { Socio- } \\
\text { demographic } \\
\mathrm{s}\end{array}$ & $\begin{array}{l}\text { Response } \\
\text { category }\end{array}$ & $\begin{array}{c}\text { Burkina } \\
\text { Faso } \\
(\%)\end{array}$ & Ghana (\%) \\
\hline Age & $18-29$ & $\begin{array}{c}18 \\
(20 \%)\end{array}$ & $9(6 \%)$ \\
\cline { 2 - 4 } & $30-39$ & 30 & $44(30 \%)$ \\
\hline
\end{tabular}




\begin{tabular}{|c|c|c|c|}
\hline & \multicolumn{3}{|c|}{$(33 \%)$} \\
\hline & $40-49$ & $\begin{array}{c}19 \\
(21 \%)\end{array}$ & $53(36 \%)$ \\
\hline & $50-59$ & $\begin{array}{c}14 \\
(16 \%)\end{array}$ & $32(21 \%)$ \\
\hline & $60+$ & $9(10 \%)$ & $10(7 \%)$ \\
\hline \multirow[t]{2}{*}{ Gender } & Male & $\begin{array}{c}45 \\
(50 \%)\end{array}$ & $97(66 \%)$ \\
\hline & Female & $\begin{array}{c}45 \\
(50 \%)\end{array}$ & $51(34 \%)$ \\
\hline \multirow[t]{5}{*}{ Education } & $\begin{array}{l}\text { No formal } \\
\text { education }\end{array}$ & $\begin{array}{c}55 \\
(60 \%)\end{array}$ & $84(57 \%)$ \\
\hline & Primary & $\begin{array}{c}18 \\
(20 \%)\end{array}$ & $24(16 \%)$ \\
\hline & $\begin{array}{c}\text { Junior high } \\
\text { school }\end{array}$ & $9(10 \%)$ & $18(12 \%)$ \\
\hline & $\begin{array}{c}\text { Senior high } \\
\text { school }\end{array}$ & $4(5 \%)$ & $17(11 \%)$ \\
\hline & $\begin{array}{c}\text { Tertiary } \\
\text { education }\end{array}$ & $4(5 \%)$ & $5(4 \%)$ \\
\hline \multirow[t]{5}{*}{ Occupation } & Artisan & $2(2 \%)$ & $0(0 \%)$ \\
\hline & Farmer & $\begin{array}{c}63 \\
(70 \%)\end{array}$ & $146(98 \%)$ \\
\hline & Student & $3(3 \%)$ & $1(1 \%)$ \\
\hline & Teacher & $6(7 \%)$ & $0(0 \%)$ \\
\hline & Trader & $\begin{array}{c}16 \\
(18 \%)\end{array}$ & $1(1 \%)$ \\
\hline \multirow{6}{*}{$\begin{array}{l}\text { How long } \\
\text { (years) have } \\
\text { you lived in } \\
\text { this area? }\end{array}$} & $5-10$ & $9(10 \%)$ & $55(37 \%)$ \\
\hline & $11-20$ & $\begin{array}{c}50 \\
(55 \%)\end{array}$ & $55(37 \%)$ \\
\hline & $21-30$ & $\begin{array}{c}24 \\
(27 \%)\end{array}$ & $17(11 \%)$ \\
\hline & $31-40$ & $7(8 \%)$ & $14(10 \%)$ \\
\hline & $41-50$ & $0(0 \%)$ & $3(2 \%)$ \\
\hline & $51-60+$ & $0(0 \%)$ & $4(3 \%)$ \\
\hline Total & & $\begin{array}{c}90 \\
(100 \%)\end{array}$ & $148(100 \%)$ \\
\hline
\end{tabular}

3.2 Awareness about the Volta Basin Authority and the code of conduct

In the second part of the survey, we attempted to understand respondents' awareness of transboundary water governance in the Volta Basin. First, we asked the respondents whether they knew of the Volta Basin
Authority (VBA). We also asked them whether they were aware of the code of conduct between Ghana and Burkina Faso. Finally, we asked them whether they knew of their status as key stakeholders of the VBA.

In response to the first question about awareness of the VBA, which began its operation three years after the formulation of the code of conduct, only $16 \%$ of the respondents in Burkina Faso and 9\% in Ghana answered positively. With regards to the awareness of the code, $69 \%$ of the respondents in Burkina Faso knew of it. In Ghana, only $11 \%$ answered positively. Among those respondents who were aware of the VBA, only $9 \%$ knew of their status as key stakeholders in both countries, indicating the low awareness level of the respondents (Figure 2). That only $9 \%$ in both countries recognized themselves as stakeholders means that the VBA had largely operated as a top-down institution without much public engagement or participation. Regarding the higher level of awareness about the code of conduct among the respondents in Burkina Faso than those in Ghana, the reason can be at least partially attributable to the fact that the study area in Burkina Faso houses the headquarters of the Project for Improvement of Water Governance (PAGEV) that facilitated the establishment of the code (IUCN, 2009). This agreement preceded the establishment of the VBA in 2009.

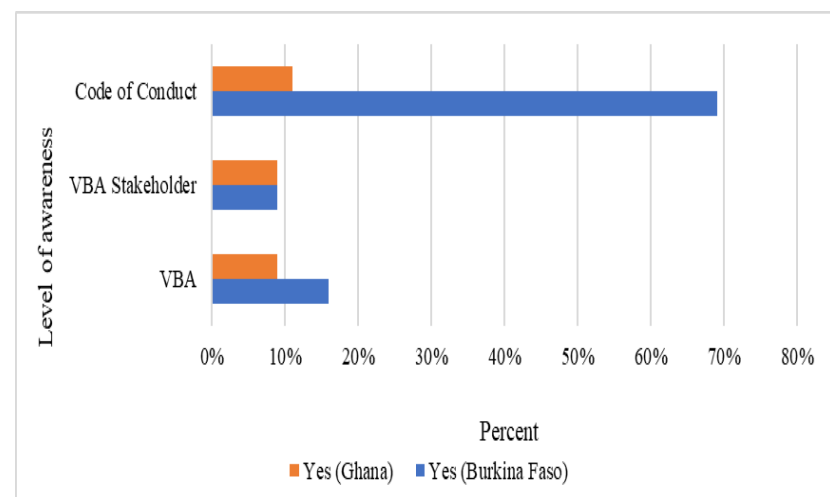

Fig. 2. Riparian communities' knowledge about the VBA and the code of conduct

Considering these results on awareness, we conducted a Chi-squared analysis to gain further insights on correlations with socio-demographic characteristics. A crosstabulation revealed a p-value less than 0.05 $\left(\chi^{2}=4.939, \mathrm{df}=5\right.$ and $\left.\mathrm{p}<0.05\right)$ for gender (Table 2; Appendix 1). This means that gender had a significant correlation with respondents' awareness. More males $(87.5 \%)$ than females were aware of their status as key VBA stakeholders in Burkina Faso. Similar gender differences exist in Ghana, but it was not statistically significant. This regional deviation could partly be 
explained by the fact that men generally dominate in community meetings and external workshops that discuss issues about the Volta River Basin. Also, the presence of teachers and traders in Burkina Faso might have affected this result to some extent.

Table 2. Correlations between gender and respondents' knowledge about the VBA

\begin{tabular}{lll}
\hline $\begin{array}{c}\text { Cross- } \\
\text { tabulation }\end{array}$ & \multicolumn{1}{c}{$\begin{array}{c}\text { Gender } \\
\text { (Ghana) }\end{array}$} & $\begin{array}{l}\text { Gender } \\
\text { (Burkina Faso) }\end{array}$ \\
\hline $\begin{array}{l}\text { Are you aware of } \\
\text { the VBA? }\end{array}$ & $\begin{array}{l}0.903 \\
(0.342)\end{array}$ & 3.045 \\
$\begin{array}{l}\text { Are you a VBA } \\
\text { stakeholder? }\end{array}$ & 0.903 & 4.939 \\
$\begin{array}{l}\text { Have you heard } \\
\text { about code of } \\
\text { conduct? }\end{array}$ & 2.014 & $(0.342)$ \\
\hline
\end{tabular}

About correlations between education and awareness, our analysis found a p-value of less than 0.05 in Ghana $\left(\chi^{2}=36.181, \mathrm{df}=5\right.$ and $\left.\mathrm{p}<0.05\right)$. This means that education had a significant correlation with respondents' awareness. Among those Ghanaian respondents without formal education, 99\% was not aware of the VBA. Those with senior high school and tertiary education, $35 \%$ and $75 \%$ knew of the VBA, respectively. Similarly, regarding the awareness of the code among the Ghanaian respondents, $95 \%$ of those without formal education did not know about it while $30 \%$ and $75 \%$ of those with senior high school and tertiary education did. Regarding their awareness of being key VBA stakeholders, 99\% of those without formal education answered negative whereas $35 \%$ and $75 \%$ of those with senior high school and tertiary education gave positive answers.

In Burkina Faso, however, we found that education had a significant correlation only with respondents' awareness of being key stakeholders. Here, $98 \%$ of those without formal education did not know of their status of being key stakeholders, compared with $33 \%$ of those with junior high school education. Among those with tertiary education, $50 \%$ did not know of being stakeholder (Table 3; Appendix 2).

Table 3. Correlations between education and respondents' knowledge about the VBA

\begin{tabular}{lrr}
\hline Cross-tabulation & $\begin{array}{c}\text { Education } \\
\text { (Ghana) }\end{array}$ & $\begin{array}{c}\text { Education } \\
\text { (Burkina Faso) }\end{array}$ \\
\hline $\begin{array}{l}\text { Are you aware of the } \\
\text { VBA? }\end{array}$ & 36.181 & 7.406 \\
& $\left(0.000^{*}\right)$ & $(0.116)$ \\
\hline
\end{tabular}

\begin{tabular}{lrr}
\hline Are you a VBA & 36.181 & 14.771 \\
stakeholder? & $(0.000 *)$ & $(0.005$ \\
& & $*)$ \\
Have you heard about & 22.024 & 2.421 \\
code of conduct? & $(0.000 *)$ & $(0.659)$ \\
\hline
\end{tabular}

Years of residency also significantly influenced respondents' knowledge as being key stakeholders. Among those who had lived in the study area for 11-20 and 21-30 years, $6 \%$ and $8 \%$ knew of their status as stakeholders, respectively. Also, $33 \%$ of those who had lived for 5-10 years knew about their status. Regarding the knowledge about the code of conduct, $92 \%$ of the respondents who had lived in the Basin for 21-30 years knew about it whereas $62 \%$ of those who had lived for 510 years were also aware $\left(\chi^{2}=8.443, \mathrm{df}=5\right.$ and $\left.\mathrm{p}<0.05\right)$ (Table 4; Appendix 3). In Ghana however, no significant correlation was found with their years of residency regarding all three questions. This result suggests that, overall, all residents were not well-informed about the VBA.

Table 4. Correlations between years of residency and respondents' knowledge about the VBA

\begin{tabular}{lr}
\hline \multicolumn{1}{c}{ Cross-tabulation } & $\begin{array}{l}\text { How long have you } \\
\text { lived along the Volta } \\
\text { river? (Burkina Faso) }\end{array}$ \\
\hline Are you a VBA stakeholder? & 0.342 \\
& $\left(0.049^{*}\right)$ \\
Have you heard about code of & 8.443 \\
conduct? & $\left(0.038^{*}\right)$ \\
\hline
\end{tabular}

Since stakeholder's awareness is essential for effective behavioral change (Koop et al., 2017) and appropriate and timely information dissemination enhances public awareness (Mayunga, 2007), these results may help water managers of the Volta Basin identify social aspects of water governance challenges to forestall possible conflict situations in the future. In particular, at least junior high school education is essential for all residents. For adult and elderly populations, community durbars, mosques, churches, and local chiefs (town crier) may play important roles in better informing riparian communities.

3.3 Riparian community's challenges in water governance

In addition to awareness, we tried to identify challenges the respondents face when they participate in water governance. Based on past studies and our field observation, we formulated a list of possible water governance challenges and presented these to them. The 
respondents were asked to rank the challenges in order of importance (important, not important, not sure). The challenges presented to the respondents are: (1) inadequate enforcement of environmental regulations, (2) poor community participation in governance, (3) insufficient flood prevention, and (4) untimely information about spillage from Bagre Dam.

The result shows that the respondents in Ghana (96\%) and Burkina Faso (97\%) ranked the timeliness of spillage information as the most important. Our in-person interviews also found that farmers located below the Bagre Dam were left without sufficient information about the spillage. As a result, their farms were overly flooded, and their livelihoods were significantly affected. The second most important challenge was flood prevention with $92 \%$ in Ghana and $95 \%$ in Burkina Faso. The challenge of inadequate legal enforcement was also found high in Ghana (90\%) and Burkina Faso (92\%). Poor community participation was identified by $88 \%$ of the Ghanaian and $91 \%$ of the Burkinabe respondents (Table 5). Overall, these answers suggest serious governance failure in the two study areas. These findings positively correspond with past studies that found governance problems under the Volta Basin Authority (Opoku-Ankomah et al., 2006; Gao and Margolis, 2009; Obrecht and Mead, 2014; World Bank 2015; Yankey, 2019).

Table 5. Ranking of water governance challenges by the respondents

\begin{tabular}{lccc}
\hline Challenges & \multicolumn{3}{c}{$\begin{array}{c}\text { Burkina Faso } \\
\text { Ghana }\end{array}$} \\
\cline { 2 - 4 } & $\begin{array}{c}\text { Not } \\
\text { important }\end{array}$ & Important & $\begin{array}{c}\text { I don’t } \\
\text { know }\end{array}$ \\
\hline $\begin{array}{l}\text { Enforcing } \\
\text { regulation }\end{array}$ & $5(6 \%)$ & $83(92 \%)$ & $2(2 \%)$ \\
\hline Public & $10(7 \%)$ & $134(90 \%)$ & $4(3 \%)$ \\
participation & $12(8 \%)$ & $131(88 \%)$ & $5(4 \%)$ \\
\hline $\begin{array}{l}\text { Flood } \\
\text { prevention }\end{array}$ & $4(4 \%)$ & $85(95 \%)$ & $1(1 \%)$ \\
\hline $\begin{array}{l}\text { Untimely } \\
\text { information } \\
\text { of spillage }\end{array}$ & $2(2 \%)$ & $136(92 \%)$ & $6(4 \%)$ \\
\hline
\end{tabular}

\section{CONCLUSIONS}

This research assessed the level of awareness and perceptions among Volta Basin Authority (VBA) stakeholders in Ghana and Burkina Faso. Our findings revealed that only a small portion of the respondents had a knowledge of the Volta Basin Authority and the existence of the code of conduct. Concerning the awareness, most of the respondents in Burkina Faso (84\%) and Ghana (91\%) did not know about the VBA. Also, $89 \%$ of them in Ghana did not know about the code of conduct. Furthermore, $91 \%$ in both countries did not know that they were key stakeholders of the VBA.

Through statistical analyses, we found correlations between awareness and gender, education, and years of residency with some regional variations. More males in Burkina Faso were aware of being key VBA stakeholders. In Ghana, education appeared to have affected respondents' awareness. The respondents with senior high and tertiary education in Ghana tend to be aware. Years of residency in Bagre District of Burkina Faso showed a significant correlation to their awareness. Among those who had lived for 21-30 years in the study area, 92\% knew of the code of conduct.

Regarding the four pre-identified challenges of water governance, more than $90 \%$ of the respondents in both countries similarly found seriousness of all these challenges. In particular, water spillage from Bagre Dam was the most pressing concerns. The other challenges are related to inadequate flood prevention structures and the inadequate enforcement of environmental regulations. All these suggest that the residents knew well about what challenges needed to be addressed to secure their livelihood, but they did not know how their voice can be represented on transboundary water governance matters.

If properly executed, the VBA can provide a powerful avenue for residents to express their needs and monitor progress. We recommend that the VBA regularly disseminate sufficient information about its potential roles to its stakeholders. Local transboundary committees already exist in these two study areas for different purposes. Therefore, a similar committee for water governance, especially on flood protection policies, should be formed by inviting representation from local communities. More women should be invited in local transboundary water governance committees and other water governance programs to improve their participation.

\section{ACKNOWLEDGMENT}

We are very grateful to all 238 riparian community members in Ghana and Burkina Faso who cooperated with us and provided information for this research during our field survey.

\section{CONFLICT OF INTEREST}

We declare no conflict of interest. 


\section{DISCLOSURE STATEMENT}

This research work did not receive any funding.

\section{REFERENCES}

[1] Agyenim, J. B. (2011). Investigating institutional arrangements for integrated water resource management in developing countries: The case of white Volta Basin, Ghana. PhD thesis, Vrije Universiteit.

[2] Ampomah, B. Y., Adjei, B. A., and Youkhana, E. (2008). The transboundary water resources management regime of the Volta Basin (No. 28). ZEF Working Paper Series.

[3] Ampomah, O. (2017). Modeling the Effect of the Bagre Dam on the Water Levels of the Akosombo Dam: Time Series Intervention Analysis. PhD thesis, University of Ghana.

[4] Amuquandoh, M. K. (2016). An Assessment of the Effects of the Bagre Hydro Dam Spillage on Ghana-Burkina Faso Relations. Master's thesis. University of Ghana. https://pdfs.semanticscholar.org/3ad4/2e5ebdd15055b4f2bc 9cf52847ba73373be6.pdf (accessed 2 May 2020).

[5] Andreini, M. (2002). Water sharing in the Volta basin: Bridging the Gap between Research and Practice. Regional Hydrology. IAI IS publ. No. 274.

[6] Baah-kumi, B., and Ward, F. A. (2020). Poverty mitigation through optimized water development and use: Insights from the Volta Basin. Journal of Hydrology, 582, 124548. https://doi.org/10.1016/j.jhydrol.2020.124548.

[7] Chacko, C. J. (1932). The International Joint Commission between the United States and the Dominion of Canada. New York: Columbia University Press.

[8] CityPopulation. https://citypopulation.de/php/burkinafaso-communesadmin.php?adm2id=BF480101 (accessed 15 April 2020).

[9] Coche, A. G. (1998). Supporting Aquaculture Development in Africa: Research Network on Integration of Aquaculture and Irrigation. CIFA Occasional Paper. No. 23. Accra. http://www.fao.org/3/X5598E/X5598E00.htm (accessed 8 July 2020).

[10] Construction Review Online. (2020). Construction of Pwalugu multipurpose dam in Ghana to start in April 2020. https://constructionreviewonline.com/2020/03/construction -of-pwalugu-multipurpose-dam-in-ghana-to-start-in-april2020/ (accessed 13 July 2020).

[11] Gao, Y., and Margolies, A. (2009). Transboundary water governance in the Volta River Basin. https://wikis.uit.tufts.edu/confluence/display/aquapedia/Tra nsboundary+Water+Governance+in+the+Volta+River+Bas in (accessed 2 May 2020).

[12] Gerlak, A.K., and Schmeier, S., (2018). River Basin Organizations and the Governance of Transboundary Watercourses. In the Oxford Handbook of Water Politics and Policy, edited by K. Conca and E. Weinthal, pp. 532548. Oxford University Press.

[13] Ghana Statistical Service-Bawku Municipality. (2014). District Analytical Report-Bawku Municipality. Population and Housing Census. 1-71. Retrieved from
http://www.statsghana.gov.gh/docfiles/2010_District_Repo rt/Upper East/BawkuMunicipality.pdf.

[14] Ghana Statistical Service-Garu. (2014). District Analytical Report-Garu Tempane District. Population and Housing Census. 1-79. Retrieved from http://www2.statsghana.gov.gh/docfiles/2010_District_Rep ort/Upper\%20East/GARU\%20TEMPANE.pdf.

[15] Global Water Partnership. (2014). Outlines and Principles for Sustainable Development of the Volta Basin. https://www.gwp.org/globalassets/global/gwpwaf_files/wacdep/brochure_outlines_principles_wacdep_ab v_en.pdf (accessed 17 December 2019).

[16] Gyireh, P. F., and Nunbogu, A. M. (2015). Sustainable management of flood disasters in the Upper East Region, Ghana. International Journal of Development and Sustainability. 4(5), 549-562.

[17] IEADB (International Environmental Agreements Database Project). (2020). Convention on the status of the Volta River and the Establishment of Volta Basin Authority. https://iea.uoregon.edu/treaty-text/2007voltabasinauthorityentxt (accessed 5 August 2020).

[18] International Institute for Environment and Development (IIED). (2020). Global Water Initiative: Burkina Faso Project 2008-2017. https://www.iied.org/global-waterinitiative-burkina-faso (accessed 9 July 2020).

[19] Islam, S., and Susskind, L. (2013). Water Diplomacy: A Negotiated Approach to Managing Complex Water Networks. Routledge.

[20] IUCN. (2009). Improving Water Governance in the Volta Basin-Phase 2, PAGEV (2).

https://www.iucn.org/sites/dev/files/import/downloads/page v_ii.pdf (accessed 9 August 2020).

[21] IUCN. (2012). Volta River Basin: Ghana and Burkina Faso. Transboundary water management through multilevel participatory governance and community projects. IUCN Water Programme, Demonstration Case study No.4. IUCN, Water and Nature Initiative (WANI). https://portals.iucn.org/library/node/10108 (accessed 22 April 2020).

[22] Kent State University Libraries. (2020). SPSS Tutorials: Chi-square Test of Independence. https://libguides.library.kent.edu/SPSS/ChiSquare (accessed 26 April 2020).

[23] Koop, S. H. A., Koetsier, L., Doornhof, A., Reinstra, O., Van Leeuwen, C. J., Brouwer, S., ... and Driessen, P. P. J. (2017). Assessing the Governance Capacity of Cities to Address Challenges of Water, Waste, and Climate Change. Water Resources Management, 31(11), 3427-3443. https://doi.org/10.1007/s11269-017-1677-7.

[24] Leemhuis, C., Jung, G., Kasei, R., and Liebe, J. (2009). The Volta Basin Water Allocation System: Assessing the impact of small-scale reservoir development on the water resources of the Volta Basin, West Africa. Advances in Geosciences, 21, 57-62.

[25] Mathews, M. (2012). The Volta Convention: An effective tool for transboundary water resource management in an era of impending climate change and devastating natural 
disasters. Denver Journal of International Law \& Policy, 41(2), 273-308.

[26] Mayunga, J. S. (2007). Understanding and applying the concept of community disaster resilience: a capital-based approach. Summer Academy for Social Vulnerability and Resilience Building, 1(1), 1-16.

[27] MOFA (Ministry of Food and Agriculture). (2015). Facts and Figures, 2015. http://agricinghana.com/wpcontent/uploads/2017/07/AGRICULTURE-IN-GHANAFacts-and-Figures-2015.pdf (accessed 11 December 2019).

[28] Mul, M., Obuobie, E., Appoh, R., Kankam-Yeboah, K., Bekoe-Obeng, E., Amisigo, B., and McCartney, M. (2015). Water resources assessment of the Volta River Basin (Vol. 166). International Water Management Institute (IWMI).

[29] Obrecht, A., and Mead, N., (2014). Cross border risks and transboundary risk governance in West Africa: Case study of the Volta River Basin.

[30] Opoku-Ankomah, Y., Dembélé, Y., Ampomah, B. Y., and Somé, L. (2006). Hydro-political assessment of water governance from the top-down and review of literature on local level institutions and practices in the Volta Basin (Vol. 111). International Water Management Institute (IWMI).

[31] Priscoli, J. D., and Wolf, A. T. (2009). Managing and Transforming Water Conflicts. Cambridge University Press.

[32] Schmeier, S. (2013). Governing International Watercourses: River Basin Organizations and the Sustainable Governance of Internationally Shared Rivers and Lakes. Routledge.

[33] UNEP-GEF Volta Project. (2013). Volta Basin Transboundary Diagnostic Analysis. UNEP/GEF/Volta/RR 4/2013.

[34] World Bank Group. (2020). Life Expectancy at Birth, total years.

https://data.worldbank.org/indicator/SP.DYN.LE00.IN (accessed 8 July 2020).

[35] Welling, R., Cartin, M., Baykono, D., and Diallo, O. Transboundary Water Management Through Multi-Level Participatory Governance and Community Projects. Ghana and Burkina Faso. Water and Nature Initiative (WANI) Case Study.

[36] Wolf, A. T., Yoffe, S. B., and Giordano, M. (2003). International Waters: Identifying Basins at Risk. Water Policy, 5(1), 29-60.

[37] World Bank. (2015). Project appraisal document on proposed grants to the Volta basin authority from the cooperation in international waters in Africa trust fund and the global environment facility for a Volta river basin strategic action programme implementation project. Global Water Practice (GWADR), Africa Region.

[38] Yankey, I. K. (2019). Ghana's Water Relations with Burkina Faso: Hydropolitical Standpoint (Master's thesis, Sosyal Bilimler Enstitüsü). http://www.openaccess.hacettepe.edu.tr:8080/xmlui/handle/ 11655/6050 (accessed 2 May 2020).
Appendix 1. Cross-tabulation on gender, riparian awareness of VBA, being key a stakeholder?

\begin{tabular}{|c|c|c|c|}
\hline & & Ghana & Burkina Faso \\
\hline 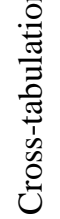 & 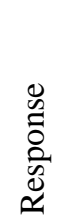 & male female & male female \\
\hline
\end{tabular}

\begin{tabular}{|c|c|c|c|c|c|}
\hline & no & 86 & 48 & 35 & 41 \\
\hline 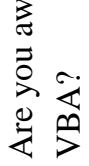 & yes & 10 & 3 & 10 & 4 \\
\hline
\end{tabular}

\begin{tabular}{|c|c|c|c|c|c|}
\hline \multicolumn{6}{|c|}{ Sub-Total } \\
\hline & & 96 & 51 & 45 & 45 \\
\hline \multirow{2}{*}{ 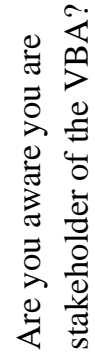 } & no & 86 & 48 & 38 & 44 \\
\hline & yes & 10 & 3 & 7 & 1 \\
\hline
\end{tabular}

\begin{tabular}{|c|c|c|c|c|c|}
\hline Sub-Total & & 96 & 51 & 45 & 45 \\
\hline 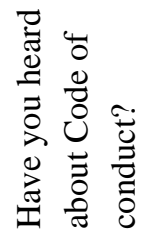 & no & 83 & 48 & 15 & 13 \\
\hline
\end{tabular}

yes $\quad 13 \quad 3 \quad 29$

29

31

$\begin{array}{lllll}\text { Sub-Total } & 96 & 51 & 44 & 44\end{array}$


Appendix 2. Cross-tabulation on level of education, riparian awareness about VBA, code of conduct and status as key stakeholder.

\begin{tabular}{|c|c|c|c|c|c|c|}
\hline \multirow[b]{2}{*}{ 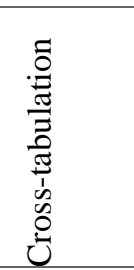 } & \multirow[b]{2}{*}{ 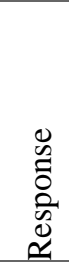 } & \multicolumn{5}{|c|}{ Burkina Faso (Ghana) } \\
\hline & & $\begin{array}{l}\text { no } \\
\text { formal } \\
\text { educatio } \\
\text { n }\end{array}$ & JHS & $\begin{array}{l}\mathrm{SH} \\
\mathrm{S}\end{array}$ & $\begin{array}{l}\text { Tertiar } \\
\mathrm{y}\end{array}$ & $\begin{array}{l}\text { Prima } \\
\text { ry }\end{array}$ \\
\hline \multirow{4}{*}{ 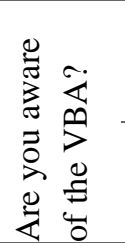 } & no & 51 & & 3 & 3 & 13 \\
\hline & & (83) & $(17)$ & (11) & (1) & (22) \\
\hline & ye & 4 & 3 & 1 & 1 & 5 \\
\hline & $\mathrm{s}$ & (1) & $(0)$ & (6) & (4) & (2) \\
\hline \multirow{2}{*}{\multicolumn{2}{|c|}{ Sub-total }} & 55 & 9 & 4 & 4 & 18 \\
\hline & & (84) & $(17)$ & (17) & (5) & (24) \\
\hline \multirow{4}{*}{ 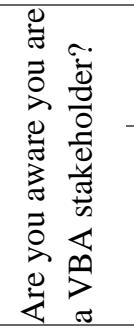 } & no & 54 & 6 & 3 & 2 & 17 \\
\hline & & (83) & (17) & (11) & (1) & $(22)$ \\
\hline & ye & 1 & 3 & 1 & 2 & \\
\hline & $\mathrm{s}$ & (1) & $(0)$ & (6) & (4) & $1(2)$ \\
\hline \multirow[t]{2}{*}{ Sub-total } & & 55 & 9 & 4 & 4 & 18 \\
\hline & & $(84)$ & (17) & (17) & $(5)$ & (24) \\
\hline \multirow{4}{*}{ 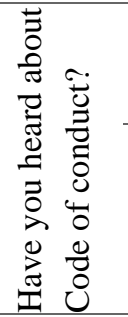 } & no & 14 & 4 & 2 & 1 & 7 \\
\hline & & (80) & $(16)$ & (12) & (1) & (22) \\
\hline & ye & 39 & 5 & 2 & 3 & 11 \\
\hline & $\mathrm{s}$ & (4) & (1) & $(5)$ & (4) & (2) \\
\hline \multirow{2}{*}{\multicolumn{2}{|c|}{ Sub-total }} & 53 & 9 & 4 & 4 & 18 \\
\hline & & (84) & (17) & (17) & & (24) \\
\hline
\end{tabular}

Appendix 3. Cross-tabulation on years of residency, riparian awareness as key stakeholders and the code of conduct.

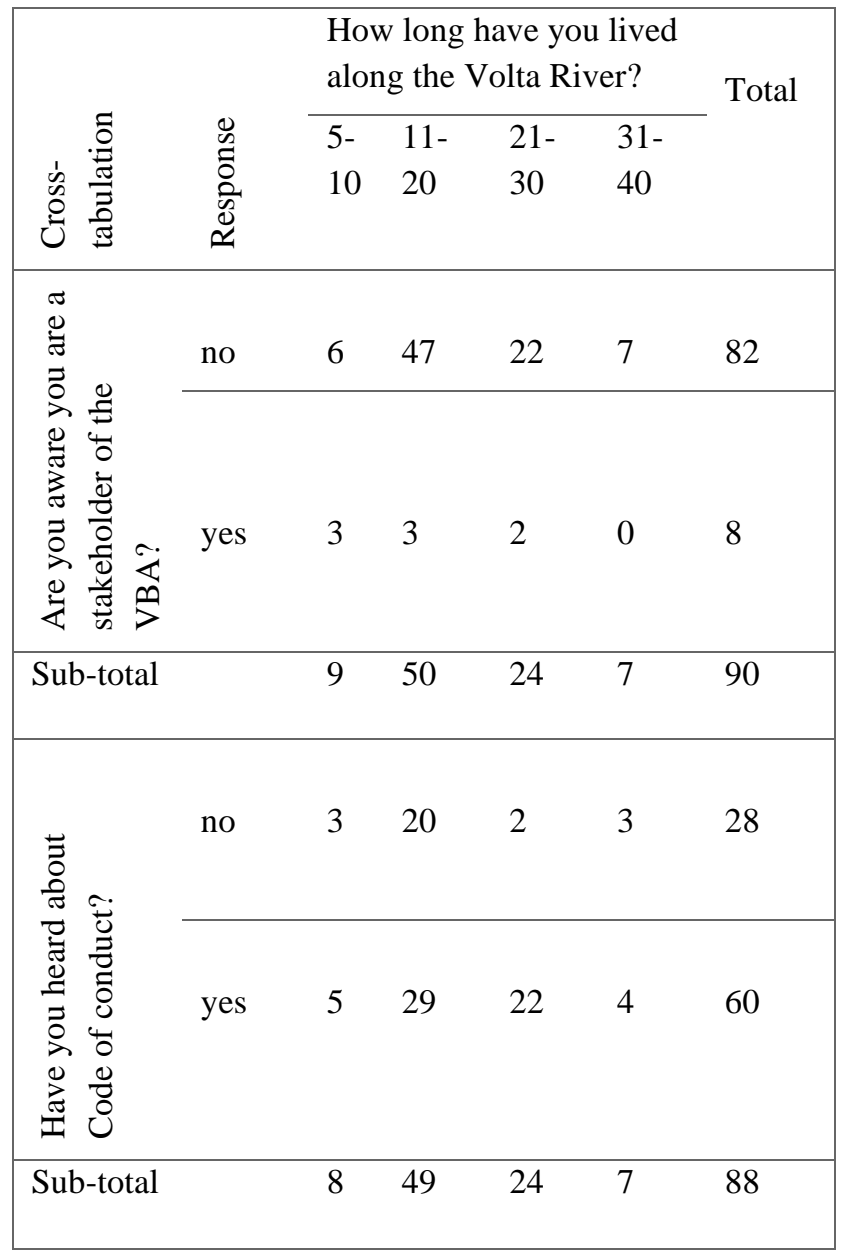

